\title{
Microwave Assisted Synthesis of Pyrimidine Carboxamide Catalyzed by Ruthenium Chloride and their Antioxidant Studies
}

\author{
K. Venkatesan \\ Asst. Professor, CVR College of Engineering/H\&S Department (Chemistry), Hyderabad, India \\ Email: venkippk@gmail.com
}

\begin{abstract}
A systematic and simple method for the preparation of pyrimidinone compound utilizing $\mathrm{RuCl3.2H2O}$ catalyst under traditional and microwave method. The preparation of dihydro pyrimidinone utilizing ruthenium chloride dihydrate had generated lots of interest which includes easy work up, less reaction period and better yields under the usage of $\mathrm{CH}_{3} \mathrm{CN}$ as a solvent. The structures of the new substances have been affirmed throgh FT-IR, ${ }^{13} \mathrm{C}$ NMR, ${ }^{1} \mathrm{H}$ NMR and mass spectra. All the new substances were screened for antioxidant nature.
\end{abstract}

Index Terms: Ruthenium chloride, Antioxidant, Microwave, Dihydropyrimidine

\section{INTRODUCTION}

The multicomponent single step reactions (MCRs) are the most used procedure in medicinal chemistry and organic synthesis. Nitrogen based compounds provides huge range of bio applications. Due to the presence of nitrogen atom it contains a lone pair electron which acts as donor group for building supramolecular blocks. MCRs are important in the field of organic synthesis, that is extensively used to prepare dissimilar target molecules in single step reaction, and in the usage of three or greater number of initial substances. In 1893 Biginelli has describe the new route for the preparation of DHPMs via a simple single step condensation reaction of ethyl acetoacetate, urea and benzaldehyde [1]. The availability is restricted for the natural products which provide interesting goals for total synthesis [2]. The DHPM is the main structure in synthesis of various pharmacological and medicinally used agents like antiviral [3], antibacterial [4], antihypertensive agents [5], antitumor [6], neuropeptic agents [7], antagonists [8], $\alpha-1 \mathrm{a}-$ antagonists [9] anti-inflammatory and $\mathrm{Ca}$ channel blockers [10]. Further, DHPM ring present in alkaloid batzelladine hinder the binding of HIV protein gp-120 to human CD4 cells and the possibility of new substances prepared for AIDS treatment [11-12]. Hence, synthesis of DHPMs shows continuous interest and attraction to organic chemists.

Recent report reveals that mortal kinesin Eg5, plays a crucial part in cellular division by organizing the bipolar group, it has been checked the consideration of drug for the advancement of cancer therapy. Monastrol, the first Biginelli compound, exhibit excellent anticancer activity. The dihyropyrimidinones derived from natural aquatic sources such as Batzelladine A, B [13] is the first low M.Wt products occurs naturally it shows good anti-HIV property and hence DPHM were examined as powerful molecules in AIDS treatment.
Biginelli reaction was carried out by mixing active 1,3dicarbonyl, different substituted aldehydes, and thiourea or

TABLE I.

EXPERIMENTAL RESUlts AND PHYSICAL DATA OF ARYLPYRIMIDINE-5-

\begin{tabular}{|c|c|c|c|c|c|c|c|c|}
\hline & & & $30 x$ & AMID & DERIV & TIVE & & \\
\hline $\begin{array}{l}\text { Co } \\
\text { mp }\end{array}$ & P & $\mathrm{D}$ & $\mathrm{Y}$ & & $\begin{array}{l}\text { ction } \\
\text { (min.) }\end{array}$ & & $(\%)^{\mathrm{a}}$ & (or) \\
\hline $\begin{array}{l}\text { ou } \\
\text { nd }\end{array}$ & K & $\mathrm{K}_{1}$ & $x$ & $\begin{array}{l}\mathrm{M} \\
\mathrm{W}\end{array}$ & Con. & $\begin{array}{l}\mathrm{M} \\
\mathrm{W}\end{array}$ & Con. & m.p. ( $\left.{ }^{2} \mathrm{C}\right)$ \\
\hline $4 a$ & $\mathrm{H}$ & Phenyl & $\mathrm{O}$ & 16 & 430 & 90 & 78 & $225-228$ \\
\hline $4 b$ & $\mathrm{H}$ & Phenyl & $\mathrm{S}$ & 17 & 440 & 88 & 81 & $214-217$ \\
\hline $4 \mathrm{c}$ & $\mathrm{H}$ & $\begin{array}{l}\text { 3-OEt-4- } \\
\text { OH-Ph }\end{array}$ & $\mathrm{O}$ & 18 & 460 & 87 & 78 & $254-256$ \\
\hline $4 \mathrm{~d}$ & $\mathrm{H}$ & $\begin{array}{l}\text { 3-OEt-4- } \\
\text { OH-Ph }\end{array}$ & $\mathrm{S}$ & 21 & 440 & 82 & 76 & $243-245$ \\
\hline $4 \mathrm{e}$ & $\mathrm{H}$ & 2,4-Cl-Ph & $\mathrm{O}$ & 21 & 460 & 83 & 77 & 207-209 \\
\hline $4 f$ & $\mathrm{H}$ & 2,4-Cl-Ph & $\mathrm{S}$ & 20 & 470 & 83 & 74 & 189-191 \\
\hline $4 \mathrm{~g}$ & $\mathrm{H}$ & $2-\mathrm{C}_{4} \mathrm{H}_{3} \mathrm{~S}$ & $\mathrm{O}$ & 17 & 400 & 84 & 78 & 191-193 \\
\hline $4 \mathrm{~h}$ & $\mathrm{H}$ & 2- $\mathrm{C}_{4} \mathrm{H}_{3} \mathrm{~S}$ & $\mathrm{~S}$ & 17 & 400 & 81 & 73 & 202-204 \\
\hline $4 \mathrm{i}$ & $\mathrm{H}$ & $\begin{array}{l}\text { Ph-4-OH- } \\
\text { 3-OMe }\end{array}$ & $\mathrm{O}$ & 18 & 410 & 87 & 82 & 231-233 \\
\hline $4 j$ & $\begin{array}{l}4- \\
\mathrm{Cl}\end{array}$ & 2,4-Cl-Ph & $\mathrm{O}$ & 16 & 450 & 86 & 80 & 206-208 \\
\hline
\end{tabular}

urea is combined with different catalysts like $\mathrm{ZrCl}_{4}$ [14], $\mathrm{Cu}(\mathrm{OTf})_{2}$ [15], $\mathrm{AcOH}$ [16], $\mathrm{CdCl}_{2}$ [17], Ionic liquids [18], $\mathrm{SiO}_{2} / \mathrm{H}_{2} \mathrm{SO}_{4}[19]$, ion-exchange resin[20], $\mathrm{La}(\mathrm{OTf})_{3}$ [21], $\mathrm{LiBr}[22], \mathrm{p}-\mathrm{TSA}[23], \quad\left(\mathrm{NH}_{4}\right)_{2} \mathrm{Ce}\left(\mathrm{NO}_{3}\right)_{6} \quad$ [24], $\mathrm{MgBr}_{2}[25]$, $\mathrm{InBr}_{3}$ [26], ultrasound irradiation[27] microwave[28] and solvent-free conditions [29], $\mathrm{ZnCl}_{2} / \mathrm{TBAB}$ [30]. $\mathrm{Co}\left(\mathrm{NO}_{3}\right)_{2} \cdot 6 \mathrm{H}_{2} \mathrm{O}$ [31], $\mathrm{Mn}(\mathrm{OAc})_{3}$ [32]. Microwave reactions have good interest in the last two decades in synthetic organic chemistry because of their low response times and excessive yield and more selectivity.

\section{A. Experimental procedure}

General: All the chemical substances had been bought from SD Fine, Aldrich and Qualigens and utilized without cleaning. The proton NMR spectra was acquired from spectrometer BRUKER AV-400 MHz with DMSO-d6 as the solvent utilizing TMS as the inner standard. The MW experiment was conducted using household MW oven with a turntable was used and the operating frequency was 2200 $\mathrm{MHz}$. Infrared (IR) spectra was recorded at room temperature with potassium bromide $(\mathrm{KBr})$ pellets utilizing 
Avatar (330) instrument with DTGS indicator. Mass spectra was obtained from JEOL 1400 HRMS spectrometer. Melting point was obtained using an open capillary tube and the results were uncorrected.

Procedure for the synthesis of pyrimidine-5-carboxamide $(4 a-j)$ :

B. Conventional Method

In a $100 \mathrm{ml} \mathrm{RB}$ flask blend of acetoaetanilide (1 milli mol), aldehyde (1 milli mol), thiourea or urea (1.5 milli mol), $\mathrm{RuCl}_{3} .2 \mathrm{H}_{2} \mathrm{O}$ (5 mole \%) and $30 \mathrm{~mL} \mathrm{CH}_{3} \mathrm{CN}$ have been refluxed according to time interim said in Table 3 . The reaction fulfillment was appeared by TLC. After completion, the reaction blend was putting into a pulverized ice, mixed for 25-30 min. The solid product obtained was filtered by using funnel, washed with large amount water and then recrystallization was done using hot ethanol to get pure products $4 \mathrm{a}-\mathrm{j}$.

\section{Microwave Irradiation}

In a small beaker acetoaetanilide ( 1 milli mol), aldehyde (1 milli mol), thiourea or urea (1.4 milli mol), $\mathrm{RuCl}_{3} \cdot 2 \mathrm{H}_{2} \mathrm{O}$ ( $5 \mathrm{~mol} \%$ ) and acetonitrile $(4 \mathrm{~mL})$ have been taken and the reaction blend were subjected to MW condition at an interim of $5 \mathrm{~min}$ at $145 \mathrm{~W}$ for around $16-22 \mathrm{~min}$; various time intervals are displayed in Table 3 . The reaction completion was observed by using TLC. After completion, the mixture was poured into ice, stirred thoroughly and the separated solid was filtered, air dried and recrystallization was done using hot ethanol to get pure products $4 a-j$. The physical properties of the prepared compounds are displayed in Table I.

Compound (4c): mp. $254-257{ }^{\circ} \mathrm{C}$; IR (KBr) vmax $\left(\mathrm{cm}^{-1}\right)$ : 3540, 3257, 2975, 2928, 1704, 1663, 1606, 1593, 1584, 1493, 1434, 1412, 1372, 1334, 1284, 1225, 1153, 1120, 1094, 1062, 1040; ${ }^{1} \mathrm{H}$ NMR (400 MHz, ppm, DMSO- $\left.d_{6},\right) \delta_{\mathrm{H}}$ 1.18-1.32 (m, $\left.\mathrm{CH}_{3}, 3 \mathrm{H}\right), 2.48\left(\mathrm{~s}, \mathrm{CH}_{3}, 3 \mathrm{H}\right), 3.77-3.84(\mathrm{~m}$, $\left.\mathrm{OCH}_{2}, 2 \mathrm{H}\right), 5.23(\mathrm{~s}, \mathrm{CH}, 1 \mathrm{H}), 6.35-7.29(\mathrm{~m}, \mathrm{Ph}-\mathrm{H}, 8 \mathrm{H})$, 7.53 (s, NH, 1H), 8.85 (s, NH \& OH, 2H), 9.13 (s, CONH, $1 \mathrm{H}) ;{ }^{13} \mathrm{C}$ NMR $\left(125.757 \mathrm{MHz}, \mathrm{ppm}, \mathrm{DMSO}-d_{6},\right) \delta_{\mathrm{C}}=164.5$, $162.3,151.7,152.5,147.8,146.7,146.5,146.4,143.1$, $142.0,135.9,131.2,128.7,127.3,126.0,125.5,119.3$, $118.0,115.7,115.5,112.6,102.5,64.2,64.1,63.8,53.1$, 37.8, 15.2, 14.9; HRMS: $\mathrm{m} / \mathrm{z}\left[\mathrm{M}^{+}\right]$calc. 367.1530; obtained: 367.1533 .

Compound (4d): mp. $243-246{ }^{\circ} \mathrm{C}$; IR (KBr) vmax $\left(\mathrm{cm}^{-1}\right)$ : 3347, 3190, 2976, 2931, 1670, 1624, 1596, 1571, 1511, $1466,1434,1400,1282,1234,1216,1189,1148,1120$, 1107, 1084, 1037, 1011; ' $\mathrm{H}$ NMR (400 MHz, ppm, DMSO$\left.d_{6}\right), \delta \mathrm{H} \quad 1.17-1.34\left(\mathrm{~m}, \mathrm{CH}_{3}, 3 \mathrm{H}\right), 2.46\left(\mathrm{~s}, \mathrm{CH}_{3}, 3 \mathrm{H}\right), 3.54-$ $3.94\left(\mathrm{~m}, \mathrm{OCH}_{2}, 2 \mathrm{H}\right), 5.24$ (s, CH, 1H), 6.38-7.26 (m, Ph-H, 8H), 8.88-8.94 (split peak, NH \& OH, 2H), 9.51 (s, NH, 1H ),10.28 (s, CONH, 1H); HRMS: m/z [M $\left.{ }^{+}\right]$calc. 383.1306; obtained: 383.1304 .

Compound (4e): mp. $207-210{ }^{\circ} \mathrm{C}$; IR (KBr) vmax $\left(\mathrm{cm}^{-1}\right)$ : 3398, 3264, 3167, 3084, 3005, 1669, 1628,1593, 1563, $1524,1498,1476,1435,1380,1334,1236,1176,1140$, 1101, 1073, $1043 \mathrm{~cm}^{-1}$; ${ }^{1} \mathrm{H}$ NMR (400 MHz, DMSO-d6, ppm), $\delta \mathrm{H} 2.02\left(\mathrm{~s}, \mathrm{CH}_{3}, 3 \mathrm{H}\right), 5.72(\mathrm{~d}, \mathrm{~J}=2.3 \mathrm{~Hz}, \mathrm{CH}, 1 \mathrm{H})$, 7.02 (t, J = 7.27 Hz, Ph-H, 1H), 7.26 (t, J = 8.2 Hz, Ph-H, 2H), 7.37 (d, J = 8.5 Hz, Ph-H, 1H), 7.51 (d, J = 7.4 Hz, Ph-
H, 3H), 7.56 (d, J = 2.6 Hz, m-Ph-H, 1H), 9.36 (s, 1H, NH), $9.86(\mathrm{~s}, \mathrm{NH}, 1 \mathrm{H}), 10.11(\mathrm{~s}, \mathrm{CONH}, 1 \mathrm{H}) ;{ }^{13} \mathrm{C} \mathrm{NMR}(100.612$ MHz, ppm, DMSO- $\left.d_{6},\right)$, $\delta \mathrm{C} 173.1,165.3,137.3,136.7$, $134.0,132.0,131.1,130.8,128.7,127.0,122.3,118.4$, 105.3, 51.4, 15.2; HRMS: $\mathrm{m} / \mathrm{z}\left[\mathrm{M}^{+}\right]$calc. 375.0541; obtained: 375.0531 .

Compound (4f): mp. $189-192{ }^{\circ} \mathrm{C}$; IR (KBr) vmax $\left(\mathrm{cm}^{-1}\right)$ : $3396,3275,3086,2361,2340,1671,1653,1628,1597$, 1561, 1541, 1521, 1496, 1471, 1438, 1329, 1233,1202, 1181, 1143, 1103, 1076, 1044; ${ }^{1} \mathrm{H}$ NMR (400 MHz, DMSO$\left.d_{6}, \mathrm{ppm}\right), \delta_{\mathrm{H}} 2.05\left(\mathrm{~s}, \mathrm{CH}_{3}, 3 \mathrm{H}\right), 5.75(\mathrm{~d}, \mathrm{~J}=2.5 \mathrm{~Hz}, \mathrm{CH}$, 1H), 7.02 (t, J = 7.26 Hz, p-Ph-H, 1H), $7.24(\mathrm{t}, \mathrm{J}=8.1 \mathrm{~Hz}$, m, m'-Ph-H, 2H), 7.39 (d, J = 8.7 Hz, o'- Ph-H, 1H), 7.51 (d, $\left.\mathrm{J}=8.8 \mathrm{~Hz}, \mathrm{o}, \mathrm{o}^{\prime} \& \mathrm{~m}^{\prime}-\mathrm{Ph}-\mathrm{H}, 3 \mathrm{H}\right), 7.54$ (d, J = 2.0 Hz, m-Ph$\mathrm{H}, 1 \mathrm{H}), 9.35$ (s, NH, 1H), 9.87 (s, NH, 1H), 10.12 (s, $\mathrm{CONH}, 1 \mathrm{H})$; HRMS (EI): $\mathrm{m} / \mathrm{z}[\mathrm{M}+]$ calc. 391.0313; obtained: 391.0315 .

Compound (4g): mp. 193-196 ${ }^{\circ} \mathrm{C}$; IR (KBr) vmax $\left(\mathrm{cm}^{-1}\right)$ : 3248, 2360, 1698, 1641, 1590, 1508, 1491, 1451, 1398, 1305, 1287, 1252, 1209, 1146, 1088, 1038, 1010; ${ }^{1} \mathrm{H}$ NMR (400 MHz, DMSO- $\left.d_{6}, \mathrm{ppm}\right), \delta_{\mathrm{H}} 2.06\left(\mathrm{~s}, \mathrm{CH}_{3}, 3 \mathrm{H}\right), 5.58(\mathrm{~d}, \mathrm{~J}$ $=3.0 \mathrm{~Hz}, \mathrm{CH}, 1 \mathrm{H}), 6.91-7.37(\mathrm{~m}, \mathrm{Ph}-\mathrm{H}, 6 \mathrm{H}), 7.57(\mathrm{~d}, \mathrm{~J}=8.0$ $\left.\mathrm{Hz}, \mathrm{o}, \mathrm{o}^{\prime}-\mathrm{Ph}-\mathrm{H}, 2 \mathrm{H}\right), 7.81$ (s, NH, 1H), 8.84 (s, NH, 1H), $9.56(\mathrm{~s}, \mathrm{CONH}, 1 \mathrm{H})$; HRMS (EI): $\mathrm{m} / \mathrm{z}\left[\mathrm{M}^{+}\right]$calc. 313.0884; obtained: 313.0882 .

Compound (4h): mp. 202-205 ${ }^{\circ} \mathrm{C}$; IR (KBr) vmax cm $\mathrm{cm}^{-1}$ ): $3367,3283,1677,1632,1565,1547,1523,1498,1476$, 1439, 1361, 1326, 1232, 1188, 1116, 1074, 1034; ${ }^{1} \mathrm{H}$ NMR (400 MHz, DMSO-d6, ppm), $\delta_{\mathrm{H}} 2.13\left(\mathrm{~s}, \mathrm{CH}_{3}, 3 \mathrm{H}\right), 5.64$ (d, J $=3.2 \mathrm{~Hz}, \mathrm{CH}, 1 \mathrm{H}), 6.96-7.68(\mathrm{~m}, \mathrm{Ph}-\mathrm{H}, 8 \mathrm{H}), 9.63(\mathrm{~s}, \mathrm{NH}$, $1 \mathrm{H}), 9.72(\mathrm{~s}, \mathrm{NH}, 1 \mathrm{H}), 10.11(\mathrm{~s}, \mathrm{CONH}, 1 \mathrm{H}),{ }^{13} \mathrm{C} \mathrm{NMR}$ (100.614 MHz, DMSO- $\left.d_{6}, \mathrm{ppm}\right), \delta_{\mathrm{C}} 173.1,163.5,147.9$, $137.9,138.6,127.5,125.7,125.6,123.2,122.3,118.7$, 106.0, 50.3, 16.5; HRMS: $\mathrm{m} / \mathrm{z}\left[\mathrm{M}^{+}\right]$calc. 329.0658; obtained: 329.0656 .

Compound (4i): mp. 231-234 ${ }^{\circ} \mathrm{C}$; IR (KBr) vmax $\left(\mathrm{cm}^{-1}\right)$ : 3410, 3284, 2363, 2340, 1683, 1652, 1626, 1597, 1538, $1521,1486,1442,1384,1330,1260,1241,1163,1123$, 1073, 1032; ${ }^{1} \mathrm{H}$ NMR (300 MHz, DMSO- $\left.d_{6}, \mathrm{ppm}\right), \delta_{\mathrm{H}} 2.07$ $\left(\mathrm{s}, \mathrm{CH}_{3}, 3 \mathrm{H}\right), 3.65\left(\mathrm{~s}, \mathrm{OCH}_{3}, 3 \mathrm{H}\right), 5.33(\mathrm{~s}, \mathrm{CH}, 1 \mathrm{H}), 6.70$ 7.55 (m, NH \& Ph-H, 9H), 8.66 (s, NH, 1H), 8.92 (s, OH, $1 \mathrm{H}), 9.51$ (s, CONH, $1 \mathrm{H}) ;{ }^{13} \mathrm{C} \mathrm{NMR}(100.614 \mathrm{MHz}$, DMSO- $\left.d_{6}, \mathrm{ppm}\right), \delta_{\mathrm{C}} 164.4,149.5,145.3,144.8,137.1$, $136.8,135.1,125.4,121.0,118.5,117.4,112.2,110.7$, 103.5, 57.4, 54.7, 19.9; HRMS: $\mathrm{m} / \mathrm{z}\left[\mathrm{M}^{+}\right]$calc. 353.1366; obtained: 353.1363 .

Compound (4j): mp. 206-209 ${ }^{\circ} \mathrm{C}$; IR (KBr) vmax $\left(\mathrm{cm}^{-1}\right)$ : 3396, 3192, 1672, 1633,1598, 1563, 1532, 1467, 1438, 1382, 1233, 1201, 1101, 1043; ${ }^{1} \mathrm{H}$ NMR (400 MHz, DMSO$\left.d_{6}, \mathrm{ppm}\right), \delta_{\mathrm{H}} 2.02\left(\mathrm{~s}, \mathrm{CH}_{3}, 3 \mathrm{H}\right) 5.73(\mathrm{~d}, \mathrm{~J}=2.2 \mathrm{~Hz}, \mathrm{CH}, 1 \mathrm{H})$, 7.26-7.31 (split peak, o' \& m'-Ph-H, 2H), 7.43 (d, $J=2.1$ $\left.\mathrm{Hz}, \mathrm{m}, \mathrm{m}^{\prime}-\mathrm{Ph}-\mathrm{H}, 2 \mathrm{H}\right), 7.51-7.53$ (m, o, o' \& m-Ph-H, 3H) 7.57 (s, NH, 1H ), 8.88 (s, NH, 1H), 9.81 (s, CONH, 1H); HRMS: m/z [M+] calc. 409.0151; obtained: 409.0141.

\section{Screening of Antioxidant Activity}

The free radical-scavenging property of prepared derivatives was predicted utilizing the standard ascorbic acid by DPPH radical scavenging method. This 
investigation is generally in view of the measurement of the consolidating ability of products towards the radical DPPH.

The extinction of absorbance of buyable radical is estimated using spectrophotometer at $517 \mathrm{~nm}$ in a dimethyl sulfoxide (DMSO) solution use of UV/Vis-spectrophotometer underneath thermostatic conditions at $25^{\circ} \mathrm{C}$. DPPH has a single electron and it has a descent absorption band observed at $517 \mathrm{~nm}$. At the point when the odd electron ends up matched, the absorption band diminishes respectively and the number of atoms becomes paired.

The change in absorbance has been widely used to test the potential of synthesized compounds to act as a radical scavenger. Therefore, faster is the lowering of absorbance; greater is the antioxidant property of the substance.

In a test tube $3.0 \mathrm{~mL}$ solution of a newly prepared DPPH of $6.02 \times 10^{-5}$ Molar solution in dimethyl sulfoxide and 100 micro litre of a DMSO solution of each synthesized product was added. After this the test sample was kept at room temperature for $30 \mathrm{~min}$ in dull condition and the absorbance of the solution was measured at $517 \mathrm{~nm}$. The control has all reagents except prepared compound. The analysis was done thrice and the average absorbance values are considered. The DPPH scavenging property was expressed in hinderance rate (I \%) as depicted by Sokmen et al., 2006[33].

Inhibition percentage $(\%)=[$ (control Optical Densitysample Optical Density)/control Optical Density] X 100.

\section{RESULTS AND DISCUSSION}

The one pot three component reaction for the synthesis of 4-aryl pyrimidine-5-carboxamide via reaction between substituted benzaldehyde, actoacetanilide, urea or thiourea using ruthenium(III) chloride dihydrate $\mathrm{RuCl}_{3} \cdot 2 \mathrm{H}_{2} \mathrm{O}$ under traditional heating and microwave irradiation methods were reported (Scheme 1). $\mathrm{RuCl}_{3} \cdot 2 \mathrm{H}_{2} \mathrm{O}$ is a powerful catalyst for the preparation of DHPM, when compared with other catalysts like Lewis acid which are represented in the old report.

\section{SCHEME I}

SYNTHETIC PROTOCOL OF COMPOUND 4A-J

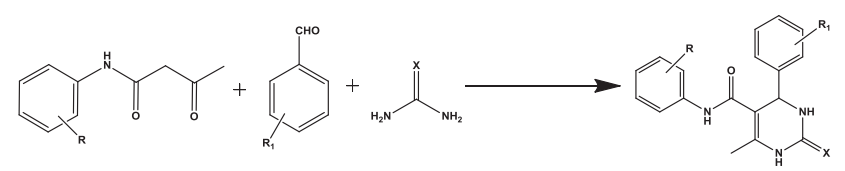

To enhance the reaction condition, the condensation reaction was chosen using acetoacetanilides, benzaldehyde and urea using $\mathrm{RuCl}_{3} \cdot 2 \mathrm{H}_{2} \mathrm{O}$ under traditional and microwave method. The different solvent systems like dichloromethane, chloroform, methanol, ethanol, acetonitrile and different synergist mole percent of catalyst was additionally analyzed and the outcomes were exhibited in Table II \& III.

Table one reveals that polar protic solvents like ethanol, methanol and acetonitrile gave high yields. In comparison the nonpolar solvent such as $\mathrm{DCM}, \mathrm{CHCl}_{3}$. Results obtained indicate that $\mathrm{CH}_{3} \mathrm{CN}$ is a suitable solvent for this conversion.

TABLE II

EFFECT OF SOLVENT SYSTEM

\begin{tabular}{|c|c|c|c|c|}
\hline S. No & Solvents & mol \% & $\begin{array}{c}\text { Time } \\
\text { (min.) }\end{array}$ & Yield (\%) \\
\hline 1 & $\mathrm{CHCl}_{3}$ & 5 & 25 & 33 \\
2 & $\mathrm{DCM}$ & 5 & 25 & 29 \\
3 & $\mathrm{C}_{2} \mathrm{H}_{5} \mathrm{OH}$ & 5 & 16 & 75 \\
4 & $\mathrm{CH}_{3} \mathrm{OH}$ & 5 & 16 & 73 \\
5 & $\mathrm{CH}_{3} \mathrm{CN}$ & 5 & 15 & 91 \\
\hline
\end{tabular}

The results indicate these reactions proceeded more effectively under microwave condition when compared with that of traditional heating. Further, impact of loading of catalyst was examined. The viable catalyst mole percent is seen to be $5 \mathrm{~mol} \%$, while expanding the mole level of catalyst did not display any improvement in the yield rate. After enhancement, the best reaction condition was utilized for preparation of 5-carboxamide dihydropyrimidine utilizing various aldehydes, thiourea or urea and different acetoacetanilide under customary warming and microwave method to produce dihydropyrimidinone substances by $\mathrm{RuCl}_{3} \cdot 2 \mathrm{H}_{2} \mathrm{O}$ as a catalyst. (Table I).

TABLE III.

EFFECT OF CATALYSTS LOADING

\begin{tabular}{|c|c|c|c|c|}
\hline S. No & Catalyst & mol \% & $\begin{array}{c}\text { Reaction } \\
\text { Period (min.) }\end{array}$ & $\begin{array}{c}\text { Yield } \\
(\%)\end{array}$ \\
\hline & & & & \\
\hline 1 & $\mathrm{RuCl}_{3} \cdot 2 \mathrm{H}_{2} \mathrm{O}$ & 5 & 15 & 91 \\
2 & $\mathrm{RuCl}_{3} \cdot 2 \mathrm{H}_{2} \mathrm{O}$ & 10 & 15 & 91 \\
3 & $\mathrm{RuCl}_{3} \cdot 2 \mathrm{H}_{2} \mathrm{O}$ & 15 & 15 & 91 \\
\hline
\end{tabular}

The catalyst $\mathrm{RuCl}_{3} \cdot 2 \mathrm{H}_{2} \mathrm{O}$ has exceptional solvency in water and is effectively evacuated by washing with water. All the prepared substances were described through spectroscopic techniques.

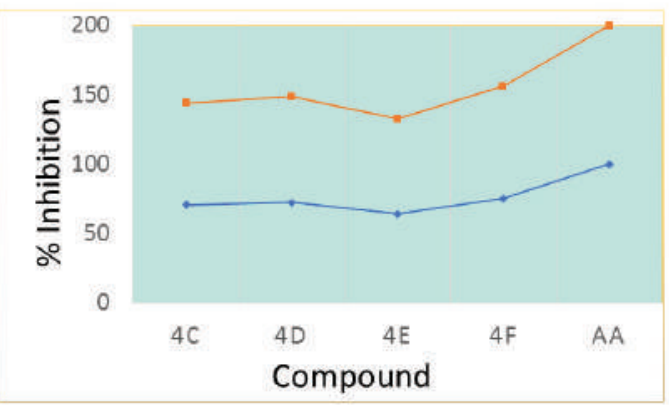

Figure 1. Comparison of antioxidant property of compound $4 \mathrm{a}-\mathrm{j}$.

\section{Antioxidant Activity}

Antioxidant studies of all the prepared compounds 4(a-j) were accomplished using radical scavenging technique. The antioxidant reports exhibited that compound $4 \mathrm{~d}, 4 \mathrm{c}, 4 \mathrm{e}$ and 4f show acceptable radical scavenging property when compared to that of standard ascorbic acid (100\%), while that of compounds $4 \mathrm{a}, 4 \mathrm{~b}, 4 \mathrm{~g}, 4 \mathrm{~h}$, and $4 \mathrm{i}$ did not indicate 
antioxidant property even at $100 \mu \mathrm{g} / \mathrm{mL}$ and one hour of incubator time.

Radical scavenging properties of the new substances $4(\mathbf{a}-\mathbf{j})$ and ascorbic acid at $100 \mu \mathrm{g} / \mathrm{mL}$ after 30 minutes and one hour of incubatory interval in dark at $25{ }^{\circ} \mathrm{C}$ are appeared in Figure. 1.

TABLE IV.

ANTIOXIDANT PROPERTY OF SUBSTANCES 4A-J UTILIZING FrEE RADICAL SCAVENGING TECHNIQUE

\begin{tabular}{|c|c|c|c|c|c|}
\hline \multicolumn{3}{|c|}{ Incubation for 30 min } & \multicolumn{3}{c|}{ Incubation for one hour } \\
\hline $\begin{array}{c}\text { Compo } \\
\text { und }\end{array}$ & $\begin{array}{c}\text { Absor } \\
\text { bance }\end{array}$ & $\begin{array}{c}\text { Antioxi } \\
\text { dant } \\
\text { activity }\end{array}$ & $\begin{array}{c}\text { Comp } \\
\text { ound. }\end{array}$ & $\begin{array}{c}\text { Absorb } \\
\text { ance }\end{array}$ & $\begin{array}{c}\text { Antioxi } \\
\text { dant } \\
\text { activity }\end{array}$ \\
\hline 4c & 2.02 & 70.68 & $4 \mathrm{c}$ & 1.93 & 73.47 \\
$4 \mathrm{~d}$ & 1.98 & 72.45 & $4 \mathrm{~d}$ & 1.75 & 76.13 \\
$4 \mathrm{e}$ & 2.59 & 64.02 & $4 \mathrm{e}$ & 2.26 & 68.81 \\
$4 \mathrm{f}$ & 1.67 & 75.34 & $4 \mathrm{f}$ & 1.43 & 80.77 \\
Control & 7.00 & & & & \\
\hline
\end{tabular}

The radical scavenging property for dimethyl sulfoxide solutions of new substances $\mathbf{4} \mathbf{a}-\mathbf{j}$ are represented in (Table 4) compared with standard ascorbic acid.

\section{CONCLUSIONS}

Easy and greener technique for the preparation of pyrimidine-5-carboxamide compounds via single step three substance cyclisation reaction of various substituted acetoacetanilides, thiourea or urea and different aldehydes under traditional heating and MW method by utilizing $\mathrm{RuCl}_{3} \cdot 2 \mathrm{H}_{2} \mathrm{O}$ catalyst. The main benefits of this procedure are moderate reaction conditions, shorter response times, easy work-up and excessive yields. The prepared substances 4a-j have been monitored for antioxidant studies using radical scavenging technique. The products $4 \mathrm{c}, 4 \mathrm{~d}, 4 \mathrm{e}$ and $4 \mathrm{f}$ showed acceptable antioxidant property when compared to that of other synthesized compounds.

\section{REFERENCES}

[1] P. Biginelli, "The condensation reaction described by Biginelli' Gazz. Chim. Ital., 23, 1983, pp. 360-416.

[2] J. Kim, C. Park, W. So, M. Jo, M. Seo and Y. Kim, "A novel 3,4-dihydropyrimidin-2(1H)-one: HIV-1 replication inhibitors with improved metabolic stability" Bioorg \& Med. Chem. Lett, 22, No. 7, pp. 2522-2526.Bioorg. Med. Chem. Lett. 22, 2012, pp. 2522-2526.

[3] C. O. Kappe, "Recent advances in the Biginelli dihydropyrimidine synthesis. New tricks from an old dog" Acc. Chem. Res, 33, 2000, pp. 879-888.

[4] M.J. Lusch and J.A. Tallarico, "Demonstration of the feasibility of a direct solid-phase split-pool Biginelli synthesis of 3,4-dihydropyrimidinones" Org. Lett, 6, 2004, pp. 3237 3240 .

[5] M. Mohammad, A. Mymoona, H. Asif, M. Akranth and H. Rashiduddin, "Anti-inflammatory and antimicrobial activityof 4,5-dihydropyrimidine-5-carbonitrile derivatives: their synthesis and spectral elucidation" Acta. Pol. Pharm. Drug. Res, 69, 2012, pp. 1077-1085.

[6] R.K. Yadlapalli, O.P. Chourasia, K. Vemuri, M. Sritharan, and R.S. Perali, "Synthesis and in vitro anticancer and antitubercular activity of diarylpyrazole ligated dihydropyrimidines possessing lipophilic carbamoyl group" Bioorg. Med. Chem. Lett, 22, 2012, pp. 2708-2711.

[7] L. Zhu, P. Cheng, C. Sheng, C. Zhuang, W. Guo, Y. Zhang, G. Dong, Z. Wang, Z. Miao and W. Zhang, "Synthesis and biological evaluation of novel homocamptothecins conjugating with dihydropyrimidine derivatives as potent topoisomerase I inhibitors" Arch. Pharm, 344, 2011, pp. 726734.

[8] N. Bhushan, S. Vasant and R. Sanjeev, "Synthesis of novel dihydropyrimidin-2 $(1 \mathrm{H})$-ones derivatives using lipase and their antimicrobial activity" Curr. Chem. Lett, 1, 2012, pp. 5968.

[9] A. D. Patil, A. J. Freyer, P. B. Taylor, B. Carte, and D.J. Faulkner, "Batzelladines F-I, novel alkaloids from the sponge batzella sp.: Inducers of p561ck-CD4 dissociation" J. Org. Chem, 62, 1997, pp. 1814-1819.

[10] S. Z. İnci, S. Selma, C. Semra and E. Kevser, "Synthesis of 4aryl-3,4-dihydropyrimidin-2(1H)-thione derivatives as potential calcium channel blockers" Bioorg. Med. Chem, 14, 2006, pp. 8582-8589.

[11] B. B. Snider, J. Chen, A. D. Patil and A. Freyer, "Synthesis of the tricyclic portions of batzelladines A, B and D. Revision of the stereochemistry of batzelladines A and D" Tetrahedron Lett, 37, 1996, pp. 6977-6980.

[12] A. V. Rama Rao, M. Gujar and J. Vasudevan, "An enantiospecific synthesis of the tricyclicguanidine segment of the anti-HIV marine alkaloid batzelladine" J. Chem. Soc. Chem. Commun, 1995, 1995, pp. 1369-1370.

[13] A. D. Patil, N. V. Kumar, D. Truneh, J. Faulkner, B. Carte, A. L. Breen, R. P. Hertzberg, R. K. Johnson, J. W. Westley and B.V. Potts, "Novel alkaloids from the sponge batzella sp.: Inhibitors of HIV gp120-human CD4 binding" J. Org. Chem, 60, 1995, pp. 1182-1188.

[14] V. A. Mamedov, L. V. Mustakimova, A. T. Gubaidullin,S. V. Vdovina, I. V. Litvinov and V. S. Reznik "Dichloroacetylaroylmethanes as two-carbon synthons in the Biginelli reaction" Chem. Heterocycl. Comp, 42, 2006, pp. 1229-1232.

[15] C. V. Reddy, M. Mahesh, T. R. Babu and V. N. Reddy, "Zirconium(IV) chloride catalyzed one-pot synthesis of 3,4dihydropyrimidin-2(1H)-ones" Tetrahedron Lett, 43, 2002, pp. $2657-2659$

[16] A. S. Prabhakar, G. K. Dewkar and A. Sudalai, "Cu(OTf)2: a reusable catalyst for high-yield synthesis of 3,4dihydropyrimidin-2(1H)-ones" Tetrahedron Lett, 44, 2003, pp. 3305-3308.

[17] Y. Ma, C. Qian, L. Wang and M. Yang, "Lanthanide triflate catalyzed Biginelli reaction. One-pot synthesis of dihydropyrimidinones under solvent-free conditions" J. Org. Chem, 65, 2000, pp. 3864-3868.

[18] C. O. Kappe, D. Kumar, and R. S. Varma, "Microwave assisted high speed parallel synthesis of 4-Aryl-3,4dihydropyrimidin- $2(1 \mathrm{H})$-ones using a solventless Biginelli condensation protocol" Synthesis, 1999, 1999, pp. 1799-1803.

[19] L. Wu, F. Yan and C. Yang, "Silica sulfuric acid promoted one-pot synthesis of benzo[4,5]imidazo[1,2-a]pyrimidine derivatives under solvent-free conditions" Bull. Chem. Soc. Ethiop, 24, 2010, pp. 417-423.

[20] J. Peng and Y. Deng, "Ionic liquids catalyzed Biginelli reaction under solvent-free conditions" Tetrahedron Lett, 42, 2001, pp. 5917-5919.

[21] J. C. Bussolari and P. A. McDonnell, "A new substrate for the Biginelli cyclocondensation: Direct preparation of 5unsubstituted 3,4-dihydropyrimidin-2(1H)-ones from a $\beta$-keto carboxylic Acid” J. Org. Chem, 65, 2000, pp. 6777-6779.

[22] G. Maiti, P. Kundu and C. Guin, "One-pot synthesis of dihydropyrimidinones catalysed by lithium bromide: an 
improved procedure for the Biginelli reaction" Tetrahedron Lett, 44, 2003, pp. 2757-2758.

[23] I. T. Phucho, S. Tumtin, A. Nongpiur, R. Nongrum and R.L. Nongkhlaw, "Microwave assisted synthesis of 6-methyl1,2,3,4-tetrahydro-N-aryl-2-oxo-4-arylpyrimidine-5carboxamide and 3, 4-dihydropyrimidin- 2(1H)-ones under solvent free conditions" J. Chem. Pharm. Res, 2, 2010, pp. 214-222.

[24] J. S. Yadav, K. B. Reddy, K. S. Raj and A. R. Prasad, "Ultrasound-accelerated synthesis of 3,4-dihydropyrimidin$2(1 \mathrm{H})$-ones with ceric ammonium nitrate" J. Chem. Soc. Perkin Trans, 2001, 2001, 1939-1941.

[25] H. Salehi and Q. X. Guo, "A facile and efficient one-Pot synthesis of dihydropyrimidinones catalyzed by magnesium bromide under solvent-free conditions" Synn. Comm, 34, 2004, pp. 171-179.

[26] N. Y. Fu, Y. F. Yuan, Z. Cao, J. T. Wang and C. Peppe, "Indium(III) bromide-catalyzed preparation of dihydropyrimidinones: improved protocol conditions for the Biginelli reaction" Tetrahedron, 58, 2002, pp. 4801-4807.

[27] J. T. Li, J. F. Han, J. H. Yang and T. S. Li, "An efficient synthesis of 3,4-dihydropyrimidin-2-ones catalyzed by $\mathrm{NH}_{2} \mathrm{SO}_{3} \mathrm{H}$ under ultrasound irradiation" Ultrason. Sonochem, 10, 2003, pp. 119-122.

[28] J. S. Yadav, B. V. S. Reddy, E. J. Reddy and T. Ramalingam, "Microwave-assisted efficient synthesis of dihydro pyrimidines: improved high yielding protocol for the Biginelli reaction" J. Chem. Res, 2000, 2000, 354-355.

[29] K. R. Reddy, C. V. Reddy, M. Mahesh, P. V. K. Raju, "New environmentally friendly solvent free synthesis of dihydropyrimidinones catalysed by N-butyl-N,N-dimethyl- $\alpha-$ phenylethylammonium bromide" Tetrahedron Lett, 44, 2003, pp. 8173-8175

[30] O. Surendranatha Reddy, Ch. Venkata Suryanarayana, N. Sharmila, G. V. Ramana, V. Anuradha and B. Hari Babu, "Synthesis and Cytotoxic Evaluation for Some New Dihydropyrimidinone Derivatives for Anticancer Activity" Lett. Drug. Des. Discov, 10, 2016, pp. 699-705.

[31] M. Nasr-Esfahani, M. Montazerozohori, M. Aghel-Mirrezaee and H. Kashi, "Efficient and green catalytic synthesis of dihydropyrimidinone (thione) derivatives using cobalt nitrate in solvent-free conditions" J. Chil. Chem. Soc, 59, 2014, pp. 2311-2314.

[32] K. A. Kumar, M. Kasthuraiah, C. S. Reddy and C. D. Reddy, " $\mathrm{Mn}(\mathrm{OAc})_{3} \cdot 2 \mathrm{H}_{2} \mathrm{O}$-mediated three-component, one-pot, condensation reaction: an efficient synthesis of 4-arylsubstituted 3,4-dihydropyrimidin-2-ones" Tetrahedron Lett, 42, 2001, pp. 7873-7875.

[33] B. Tepe, M. Sokmen, H. A. Akpulat and Sokmen. "Screening of the antioxidant potentials of six Salvia species from Turkey" Food Chem, 95, 2006, pp. 200-204. 